\title{
VARIAÇÃO DE CONCENTRAÇÃO DE PROTEINASE K EM PROTOCOLOS DE EXTRAÇÃO DE DNA DE BOVINO
}

\author{
Lara Endres da Silva1, Danielly Beraldo dos Santos Silva1', Bruno do Amaral \\ Crispim ${ }^{1}$, Jussara Oliveira Vaini ${ }^{1}$, Alexéia Barufatti Grisolia' ${ }^{1}$, Leonardo de Oliveira \\ Seno ${ }^{1}$ \\ 1 UFGD \\ Correspondência: Lara Endres da Silva: lara.endres@gmail.com
}

RESUMO: Os procedimentos padrões para extração de DNA incluem o tratamento com proteinase $k$ e posterior incubação em banho-maria por um determinado tempo. Sendo assim, avaliar métodos de extração de DNA que minimizem a quantidade de proteinase $\mathrm{k}$ e o tempo necessário para a realização das etapas, em que seja mantida a eficiência no que tange à quantidade, qualidade e a possibilidade de amplificação por PCR do DNA extraído, é de extrema importância para os estudos moleculares baseados em ácidos nucléicos. O objetivo deste estudo foi avaliar a eficiência de protocolos de extração de DNA, variando-se a concentração de proteinase $k$ e tempo de incubação em banho-maria. O DNA foi extraído a partir de sangue periférico de bovinos. Para a extração do DNA genômico, utilizou-se oito protocolos que diferiam em concentrações de proteinase $k(0,04 \mathrm{e}$ $0,08 \mu \mathrm{g} \mathrm{mL}-1)$ em intervalos de tempo variados $(90,180,360$ minutos e overnight). O DNA foi analisado quanto à sua qualidade, quantidade e viabilidade de amplificação. Foi possível obter DNA genômico de qualidade, com concentrações e pureza satisfatórias para amplificação. Com base nas análises estatísticas, as variações no protocolo tiveram efeitos isolados, ou seja, a qualidade do DNA foi suscetível à concentração de proteinase $k$ e ao tempo no banho-maria, entretanto a quantidade de DNA das amostras foi suscetível ao tempo de incubação em banho-maria, não tendo interferência pela concentração de proteinase k. Apesar dos efeitos isolados, os parâmetros estudados influenciaram de maneira significativa na qualidade e quantidade de DNA.

Palavras-chave: material genético; quantificação; sangue periférico; viabilidade de amplificação

\section{VARIATION IN CONCENTRATION OF PROTEINASE K FOR BOVINE DNA EXTRACTION PROTOCOLS}

\begin{abstract}
Standard procedures for DNA extraction include treatment with proteinase $\mathrm{k}$ and subsequent incubation in a water bath for a while. Thus, to evaluate methods of DNA extraction to minimize the amount of proteinase $\mathrm{k}$ and time required to perform the steps in which the efficiency is maintained relative to quantity, quality and the possibility of PCR amplification of DNA extracted, it is extremely importance for molecular studies based on nucleic acids. The objective of this study was to evaluate the efficiency of DNA extraction protocols, varying the concentration of proteinase $k$ and incubation in a water bath. DNA was extracted from peripheral blood of cattle. For extraction of genomic DNA, we used eight protocols that differed in concentrations of proteinase $\mathrm{K}(0.04$ and 0.08 $\mathrm{mg} \mathrm{mL}-1)$ at various time intervals $(90,180,360$ minutes and overnight). We analyzed DNA's quality, quantity and viability of amplification. It was possible to obtain high-quality genomic DNA, with concentrations and purity suitable for amplification. Based on statistical analysis, variations in the protocol had separated effects, in other words, the quality of DNA was susceptible to the concentration of proteinase $\mathrm{k}$ and to the time in water bath, however the amount of DNA samples was susceptible to the incubation in water bath, with no interference by the concentration of proteinase $\mathrm{k}$. Despite the separate effects, the parameters studied significantly influenced the quality and quantity of DNA.
\end{abstract}

Key Words: amplification viability; genetic material; peripheral blood; quantification 


\section{INTRODUÇÃO}

A obtenção de DNA de boa qualidade e sem contaminação é imprescindível para qualquer estudo molecular (Regitano et al., 2001). Métodos diferenciados de extração de DNA são utilizados para cada espécie. Contudo, devido às condições laboratoriais e em função da variabilidade existente na composição das amostras biológicas, são necessárias algumas modificações e adaptações nos protocolos (Marengoni et al., 2006).

O DNA extraído de animais de interesse zootécnico, em especial bovinos, pode ser utilizado para vários fins, como por exemplo, diagnóstico clínico de doenças, teste de paternidade para registro genealógico, melhoramento genético, planejamento de cruzamentos e estimativa de valor genético de animais de elite (Salman e Laureano, 2006).

Geralmente os procedimentos de extração de DNA incluem o tratamento com proteinase $\mathrm{k}$ e posterior incubação em banho-maria (Hilz et al., 1975). Devido a características de estabilidade a produtos químicos [SDS (Dodecil Sulfato de Sódio), agentes quelantes, reagentes sulfídricos e inibidores da tripsina ou quimiotripsina], estabilidade térmica favorável e ampla faixa de $\mathrm{pH}$, a proteinase $k$ não apresenta especificidade significativa para clivar proteínas hidrofóbicas, encontrando aplicação na preparação de protocolos para extração de DNA e RNA (Betzel et al., 1988). Tal enzima, por sua vez, tem a ação de clivar as proteínas nas ligações peptídicas que possuam o grupo carboxila de lisina ou de arginina tendo sua atividade aumentada em temperaturas elevadas (Hubner et al.,2004).

A proteinase $\mathrm{k}$ é de fundamental importância para extrair ácidos nucléicos de boa qualidade e podendo o mesmo ser amplificado por PCR (Polymerase Chain Reaction) para posteriores análises (Oliveira et al., 2007; Cardozo et al., 2009). Entretanto não há relatos na literatura que avaliem protocolos de extração de DNA genômico bovino envolvendo variação no tempo de incubação e diferentes concentrações de proteinase $\mathrm{k}$.

Pesquisar métodos de extração de DNA que minimizem os custos e mantenham a eficiência no que tange à quantidade, qualidade e a possibilidade de amplificação por PCR do DNA extraído, é de extrema importância para estudos moleculares baseados em ácidos nucléicos. Neste contexto, o objetivo do trabalho foi avaliar protocolos de extração de DNA bovino, que apresentem diferenças de concentração de proteinase $\mathrm{k}$ e tempo variados de incubação das amostras em banho-maria, determinando dessa forma a quantidade, qualidade e a viabilidade de amplificação do DNA extraído.

\section{MATERIAL E MÉTODOS}

Para realização deste estudo foram coletados $4,5 \mathrm{~mL}$ de sangue periférico da veia jugular de dez animais pertencentes a um rebanho bovino proveniente da Fazenda São Jorge do Maracay. $O$ sangue coletado foi colocado em tubos do tipo Vacuntainer com EDTA potássico, e as amostras foram armazenadas à $-20^{\circ} \mathrm{C}$. Os procedimentos técnicos foram realizados no Laboratório de Biotecnologia aplicada à Produção Animal, Faculdade de Ciências Agrárias da Universidade Federal da Grande Dourados (FCA/UFGD).

Para a extração do DNA genômico foram aliquotados $300 \mu \mathrm{L}$ de sangue bovino em microtubos de polipropileno de $2 \mathrm{~mL}$ e acrescentou-se a quantidade de proteinase $\mathrm{k}\left(20 \mathrm{mg} \mathrm{mL}^{-1}\right)$ conforme descrito na Tabela 1. Em seguida foram adicionados em cada microtubo $500 \mu \mathrm{L}$ 
de SDS a $20 \%$ e agitados em vortex, sendo posteriormente incubados a $60^{\circ} \mathrm{C}$ em banho-maria por períodos distintos (Tabela 1).

Tabela 1 - Protocolos com diferenças na concentração de proteinase $\mathrm{k}$ e variação no tempo de incubação.

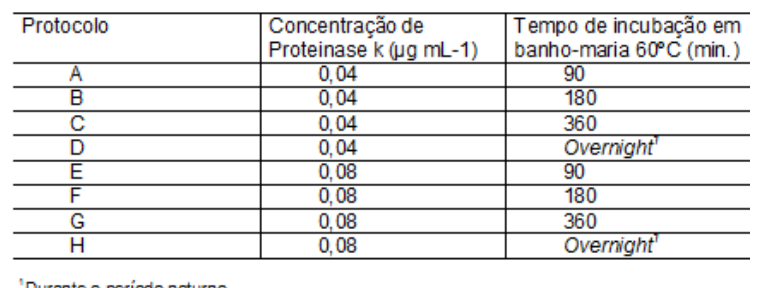

Após a incubação, foram adicionados $800 \mu \mathrm{L}$ de clorofórmio nos microtubos e agitados em vortex até completa homogeneização, em seguida, acrescentou-se $350 \mu \mathrm{L}$ de solução de precipitação protéica. Cada tubo foi novamente agitado em vortex e centrifugado por dez minutos a 14.000 $\mathrm{rpm} / 4^{\circ} \mathrm{C}$. Para solução de precipitação proteica $(10 \mathrm{~mL})$ utilizou-se: $6 \mathrm{~mL}$ de acetato de potássio $(5 \mathrm{M}) ; 1,1 \mathrm{~mL}$ de ácido acético glacial; 2,9 $\mathrm{mL}$ de água destilada, e estocou-se a $4^{\circ} \mathrm{C}$.

A fase aquosa foi retirada e transferida para outro microtubo. Adicionou-se $1 \mathrm{~mL}$ de etanol $100 \%$ gelado e logo após homogeneizou-se por inversão até a formação do precipitado. As amostras foram submetidas à centrifugação a 13.000 $\mathrm{rpm} / 4^{\circ} \mathrm{C}$ por 5 minutos, desprezou-se 0 sobrenadante. Acrescentou-se $1 \mathrm{~mL}$ de etanol $70 \%$; centrifugou-se novamente por dois minutos, descartou-se 0 sobrenadante. Após esta etapa, os microtubos foram invertidos para a secagem do sedimento sobre papel absorvente por aproximadamente 15 minutos. Após a secagem, o DNA foi ressuspendido em $100 \mu \mathrm{L}$ de TE $\mathrm{pH} 8,7$ [10 mM Tris - $\mathrm{HCl}(1 \mathrm{M}) \mathrm{pH} 7,61$ e $1 \mathrm{mM}$ EDTA $(0,1 \mathrm{M})$ ] com RNase e incubados em banho-maria $\left(37^{\circ} \mathrm{C}\right)$ por 60 minutos sendo posteriormente armazenados a $20^{\circ} \mathrm{C}$. O DNA extraído foi submetido à eletroforese em gel de agarose $2 \%$, e a pureza e concentração do DNA foram obtidas por meio de espectrofotometria.

Para monitorar a possibilidade amplificação do DNA foram realizadas PCR da região correspondente ao éxon 2 do gene da leptina utilizando os oligonucleotídeos, forward: 5'ATGCGCTGTGGACCCCTGTATC3', e reverse:

\section{5'TGGTGTCATCCTGGACCTTCC3'}

(Lara et al. 2011). As soluções para o PCR foram preparadas em um volume final de $25 \mu \mathrm{L}$, constituídos por 12,5 $\mu \mathrm{L}$ de PCR Master Mix, 10 pmoles de cada oligonucleotídeo e 50 a 100 ng de DNA genômico. As reações foram realizadas em termociclador, com 0 seguinte programa: desnaturação inicial de $94^{\circ} \mathrm{C}$ por 4', 30 ciclos de desnaturação a $94^{\circ} \mathrm{C}$ por $45^{\prime \prime}$, pareamento a $56^{\circ} \mathrm{C}$ por $55^{\prime \prime}$ e extensão a $72^{\circ} \mathrm{C}$ por $45^{\prime \prime}$, seguido da extensão final a $72^{\circ} \mathrm{C}$ por $4^{\prime}$. Os produtos de PCR foram submetidos à eletroforese em gel de agarose $2 \%$.

Os dados foram analisados em delineamento inteiramente casualizado, no esquema fatorial $2 \times 4$ (duas concentrações de proteinase $\mathrm{k}$ e quatro tempos diferentes) com dez repetições. As análises estatísticas foram efetuadas com o auxílio do pacote computacional SAS 9.2.

\section{RESULTADOS E DISCUSSÃO}

Os resultados obtidos com as análises estatísticas demonstraram que a qualidade do DNA é suscetível a concentração de proteinase $k$ e ao tempo no banho-maria. Observou-se diferença significativa $(P<0,05)$ entre as razões de DNA bovino extraído com as diferentes concentrações de proteinase k.

A maior concentração utilizada de proteinase $\mathrm{k} \quad\left(0,08 \mu \mathrm{g} \quad \mathrm{mL}^{-1}\right)$ proporcionou os melhores resultados em relação à razão, com média de 1,62 e a concentração menor $\left(0,04 \mu \mathrm{g} \mathrm{mL}^{-1}\right)$ obteve média de 1,55. Os diferentes 
tempos em banho-maria também proporcionaram diferenças significativas entre as razões $(P<0,001)$. O menor e o maior tempo utilizados (90 minutos e overnight) não diferiram estatisticamente. Porém, os melhores resultados (Média 1,79) foram obtidos com tempo de 90 minutos em banhomaria (Tabela 2). A concentração de proteinase $k$ utilizada não interferiu na concentração de DNA, no entanto, os diferentes tempos de incubação tiveram influência em relação à quantidade de DNA resultante. As amostras que ficaram em banho-maria durante 180 minutos apresentaram a maior concentração de DNA, 2,33 $\mu \mathrm{g} \mathrm{LL}^{-1}$ (Tabela 2).

Tabela 2 - Valores médios da razão e concentração obtidos nos diferentes tempos de incubação em banho-maria.

\begin{tabular}{c|c|c}
\hline $\begin{array}{l}\text { Tempos de incubação no banho- } \\
\text { maria } 60^{\circ} \mathrm{C}(\mathrm{min})\end{array}$ & Razão(260 nm/28nm) & $\begin{array}{l}\text { Concentração de } \\
\text { DNA }\left(\mu \mathrm{g} \mu \mathrm{L}^{-1}\right)\end{array}$ \\
\hline 90 & $1,79^{1}$ & $1,34^{2}$ \\
\hline 180 & $1,40^{\top}$ & $2,33^{3}$ \\
\hline 360 & $1,47^{1}$ & $1,51^{2}$ \\
\hline Overnight & $1,67^{1}$ & $1,46^{2}$ \\
\hline
\end{tabular}

'P< $0,001 .{ }^{2} N$ ão difer iram es tatis ticamente. "Diferiu es tatisticamente

Após a eletroforese em gel de agarose $2 \%$, foi possível visualizar a presença de DNA genômico em todos os protocolos testados (Figura 1). As amostras de DNA extraídas pelo protocolo $\mathrm{E}$ apresentaram características visivelmente melhores quanto à quantidade e pureza. As amostras dos protocolos B, D, F, G e H, apresentaram contaminação com proteínas, indicada pela presença de rastros no gel. Os protocolos A e C apresentaram características visivelmente inferiores em relação aos outros protocolos testados.

A avaliação eletroforética do DNA amplificado demonstrou que a extração utilizando diferentes concentrações de proteinase $\mathrm{k}$ e variações de incubação apresentou resultados satisfatórios em relação à viabilidade de amplificação do DNA obtido, com exceção da amostra 1 D (Figura 2). Segundo Regitano et al. (2001) os valores de razão de absorbância inferiores a 1,8 resultam de contaminação do DNA com proteínas, podendo inviabilizar a amplificação por PCR. No entanto para Lee et al. (2010), valores inferiores a 1,55 , como obtidos no presente estudo, podem ser considerados satisfatórios para utilização em PCR.

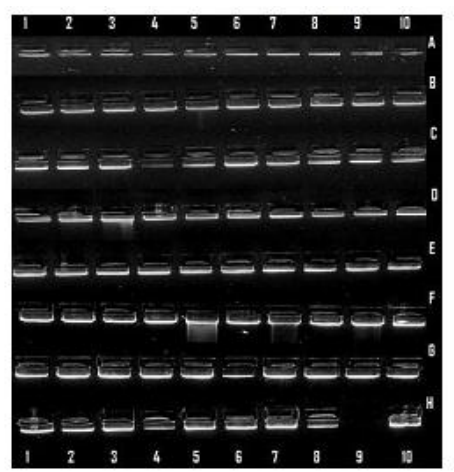

Figura 1 - Eletroforese em gel de agarose $2 \%$ de DNA genômico bovino. De 1 10 amostras de DNA, A-H Protocolos de extração. Não foi possível visualizar DNA na amostra $9 \mathrm{H}$, pois tal amostra foi perdida durante o procedimento de extração.

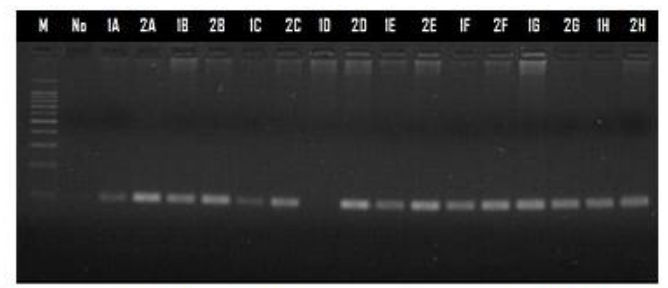

Figura 2 - Eletroforese em gel de agarose $2 \%$ de produtos de PCR Amplificação da região do éxon 2 do gene da leptina constituída de $94 \mathrm{pb}$, a partir do DNA genômico bovino. (M) marcador molecular de 100 pares de base, (No) controle negativo.

Considerando-se as condições em que o trabalho foi desenvolvido, pôde-se observar que as variações no protocolo tiveram efeitos isolados, ou seja, a qualidade do DNA é suscetível a concentração de proteinase $k$ e ao tempo no banho-maria, entretanto a quantidade de DNA das amostras foi suscetível ao tempo de incubação em banho-maria, não tendo interferência pela concentração de proteinase $\mathrm{k}$.

\section{CONCLUSÃO}

Apesar dos efeitos isolados, a concentração de proteinase $\mathrm{k}$ e intervalo de tempo de incubação em banho-maria influenciaram de maneira significativa na qualidade e quantidade de DNA bovino, demonstrando assim a importância de padronização de tais parâmetros para 
otimização de protocolos de extração de DNA.

\section{AGRADECIMENTOS}

Os autores agradecem à Agropecuária Jorge Ferreira (Fazenda São Jorge do Maracay) pela colaboração e fornecimento do material biológico. Ao Conselho Nacional de Pesquisa (CNPq), à Fundação de Apoio ao Desenvolvimento do Ensino, Ciência e Tecnologia do Estado de Mato Grosso do Sul (Fundect) e à Pró-Reitoria de Pesquisa da UFGD pelo suporte financeiro.

\section{REFERÊNCIAS}

BETZEL, C.; PAL, G. P.; SAENGER, W. Threedimensional structure of proteinase $k$ at $0.15-\mathrm{nm}$ resolution. European Journal Biochemical, v.178, p.155-171, 1988.

CARDOZO, D. M.; GUELSIN, G. A.; CLEMENTINO, S. L. et al. Extração de DNA a partir de sangue humano coagulado para aplicação nas técnicas de genotipagem de antígenos leucocitários humanos e de receptores semelhantes à imunoglobulina.

Revista da Sociedade Brasileira de Medicina Tropical, v.42, n.6, p.651-656, 2009.

HILZ, H.; WIEGERS, U.; ADAMIETZ, P. 1975.

Stimulation of proteinase $\mathrm{K}$ action by denaturing agents: application to the isolation of nucleic acids and the degradation of 'masked' proteins. European Journal Biochemical, v.56, p.103-8, 1975.

HUBNER, C. S. O.; PESCADOR, C.; COBERLLINI, L. G. et al. Otimização da imunoistoquímica para detecção de herpesvírus bovino tipo 5 (BHV-5) em tecidos do sistema nervoso central fixado com formaldeído.

Arquivos Brasileiros de Medicina Veterinária e Zootecnia, v.57, p.1-6, 2004.

LARA, M. A. C.; PINATTI, E.; FARIA, M. H. et al. Polimorfismo do gene leptina (snp305) em bovinos e sua implicação na maciez de carne. Actas Iberoamericanas de Conservación Animal, p.195-198, 2011.

LEE, J. H.; PARK, Y.; CHOI, J. R. et al. Comparisons of three automated systems for genomic DNA extraction in a clinical diagnostic laboratory. Yonsei Medical Journal, v.51, p.104-10, 2010.

MARENGONI, N. G.; MACHADO, M. R. F.; GASPARINO, E. Extração de DNA genômico em tecidos sólidos de peixes teleósteos.

Seminário: Ciências Agrárias, Londrina, v. 27, n. 1, p. 99-106, jan./mar. 2006.

OLIVEIRA, M. C. S.; REGITANO, L. C. A.; ROESE, A. D. et al. Fundamentos teóricopráticos e protocolos de extração e de amplificação de DNA por meio de reação em cadeia da polimerase. São Carlos: Embrapa Pecuária Sudeste, 2007. 43 p.

REGITANO, L. C. A.; COUTINHO, L. L.; SANTOS, I. K. F. M. et al. Biologia molecular aplicada à produção animal. Brasília: Embrapa Informação Tecnológica, 2001. 215 p.

SALMAN, A. K. D. \& LAUREANO, M. M. M. Protocolos para extração de DNA genômico de amostras de pêlo de bovinos. Comunicado técnico - Porto Velho: Embrapa RO, 2006. 